ALGIN H. NOLAN

CERTIFIED PUBLIC ACCOUNTANT

P. O. BOX 766

MT, STERLING, KENTUCKY 40353

August 9, 1982

Department of Energy

Savannah River Operations Office

Atlanta Support Office

1655 Peachtree Street, N.E.

Atlanta, Georgia 30309

\title{
Attn: Contracts/Grants
}

Re: Grant Closeout - Grant No. DE-FG44-81 R 410491

Gentlemen:

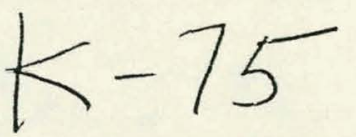

Please find enclosed the following relative to the above-referenced grant and your lefter dated July 13, 1982:

1) A finaî status report.

2) There is no final payment requested nor is a refund due.

3) The final Performance Reports is that the greenhouse has been completed and is not in use. The status report mentioned in 1) above reflects the costs, etc. I am enclosing herewith photographs of the project.

4) Two copies of our latest audit report.

5) Property Certificate.

AHN/dma

Thank you very much,

\section{Enclosures (3)}

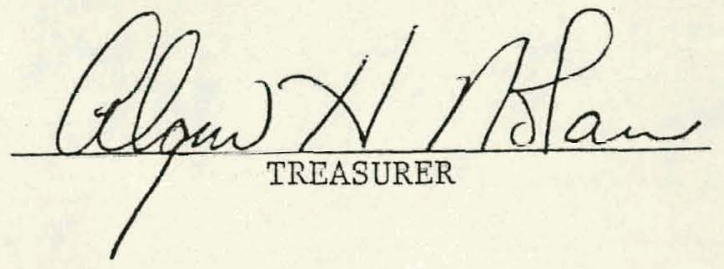

This report was prepared as an account of work sponsored by an agency of the United States Government. Neither the United States Government nor any agency thereof, nor any of their employees, makes any warranty, express or implied, or assumes any legal liability or responsibility for the accuracy, completeness, or usefulness of any information, apparalus, product, or process disclosed, or represents that its use would not infringe privately owned rights. Reference herein to any specific commercial product, process, or service by trade name, trademark, manufacturer, or otherwise does not necessarily constitute or imply its endorsement, recommendation, or favoring by the United States Government or any agency thereof. The views and opinions of authors expressed herein do not necessarily state or reflect those of the United States Government or any agency thereof.

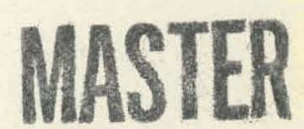

DISTRIBUTION OF THIS DOCLO

DISTRIBUTION OF THIS DOCLMENT IS UNLIMITED 


\section{DISCLAIMER}

This report was prepared as an account of work sponsored by an agency of the United States Government. Neither the United States Government nor any agency Thereof, nor any of their employees, makes any warranty, express or implied, or assumes any legal liability or responsibility for the accuracy, completeness, or usefulness of any information, apparatus, product, or process disclosed, or represents that its use would not infringe privately owned rights. Reference herein to any specific commercial product, process, or service by trade name, trademark, manufacturer, or otherwise does not necessarily constitute or imply its endorsement, recommendation, or favoring by the United States Government or any agency thereof. The views and opinions of authors expressed herein do not necessarily state or reflect those of the United States Government or any agency thereof. 


\section{DISCLAIMER}

Portions of this document may be illegible in electronic image products. Images are produced from the best available original document. 


\section{The following pages are an exact representation of what is in the original document folder.}




\section{TECHNICAL DESCRIPTION OF PROJECT}

Provide a complete and reasonably detailed technical description of your project. Explain exactly what you are going to do and how you are going to do it. Use additional pages, if needed. Provide photos, blueprints, drawings, and any supporting information you believe is necessary. Be sure that your description describes how your project will meet the technical evaluation criteria listed on page 4 . Clearly indicate any confidential information or data as instructed on page A-1.

The entry of the tenter's Admin building will be converted to a greenhouse that wraps around the entry roof to insulate tine $3:$ feet of 8 foof high windows in aluninum frames with no thermal break and the 10' $\times 38^{\prime}$ entry slab which has no thermal break from the floor of the dining room or entry. This greenhouse will wrap around the eastern wall of the dining room to provide solar gain in the morning and provide a moderating environment against the outside of the cut sandstone wall which at present provides a good conductor of heat out. The greenhouse will include a $20^{\prime} \times 12^{\prime}$ section off the receptionists office whose external wall is of 3 sheets of $6^{\prime} \times 8^{\prime}$ glass in aluminum frames with no thermal break. All glass is at present single thickness. The greenhouse is $805 \mathrm{sq} \mathrm{ft}$ of floor space. The skin of the green house is $1442 \mathrm{sq} \mathrm{ft}$ and is made bothe glas panals (where necessary to perserve the view from the dining hall) and $8 \mathrm{oz}$ fiberglass panels. The framing is of wood. The footer is to be of poured concrete extending below the frost line and is to be insulated on the outside with polystyrene and skinned with asbestos board.

The $4^{\prime} \times 8^{\prime}$ and $6^{\prime} \times 8^{\prime}$ sliding glass panels can be opened on days when there is solar gain and the dining area can be expanded into one side of the greenhouse. Results from the greenhouse will be to provide a moderating environment for the external wall and provide solar gain on an area of the building now the greatest heating problem. At present the dining hall is heated by an inadequate heat exchanger and through an under floor uninsulated concrete plenum and if there is any heat gained it is hard to feel at the registers. The windows slide in panels of three so there are three stationary windows where three hot water radiators will be installed off the existing hot water system requiring $112^{\prime}$ of $2^{\prime \prime}$ delivery pipe and insulation, and 60' of $1^{\prime \prime}$ branch piping. The radiators will be passive. These radiators wili replace and originate where the heat exchanger is at present.

l'he clerestory windows are single sheet glass in steel frames with no thermal break. The will be framed out in wood and sheeted with $80 z$. fiberglass to be visually consistant with the greenhouse and the trombe wall at the south of the building. The skin will be 100sq. ft..

The trombe wall will be made from the existing south wall of 8 "block with a 4" split concrete brick veneer with no thermal break between the two. The surface will be painted with a heat absorbing masonry paing and the walls will be ported four times at either side of the south entry-two up and two down to provide air flow. The system will be manually operated. The $385 \mathrm{sq}$ ft surface will be skinned with the same $80 z$. fiberglass panels and the framing will be wood: I might add here that fiberglass was chosen because of the high maintance of glass around 28 children from problem homes.

The rear wall of the building (north) lies against a delivery drive and can not be bermed. I had thought first to use the DRIVIT' or equivalent system for external. insulation as that kind of exterior is what is used on the US Forest Service bldg in Bered $\mathrm{Ky}$. which is the first solar and wood govermment building, and which is also much of the inspiration for the form the proposal for the children's center building is taking. $i$ I have chosen styrofoam and drywall as interior insulation and facing at \$1/sq $\mathrm{ft}$ instead of the external system at $\$ 4 / \mathrm{sq} \mathrm{ft}$.

continued on tech description $\mathrm{p} 2$ 


\section{TECHNICAL, DESCRIPTION page 2}

Overhead insulation will be of mineral fiber blown in to give an R30. It will cover 7500 sq ft.

Double glazed window units will be installed as storm windows and will give the building triple glazing from what is now single glazed aluminum sash windows with no thermal break.

There will be 182 Iineal feet of retaining wall to hold a berm against the build-ing. The retaining wall wil be $3^{\prime}$ high and will hold earth to a depth of $4^{\prime}$ agaige: the building. There will be an insulating colar of polystyrene against the concrit window sill to break the mass of the wall from the earth at the surface of the bermi The wall will be insulated with inverted throw away pop bottles and othe one-way glass containers from the food delivery and packaging chain. The placement of the bottles will be between the waterprowfed wall and the earth berm providing both free drainage and cellular glass insulation. The moment of the berm will be shifted away from the conrete brick veneered $8^{\prime \prime}$ block wall. The sifting of soil into the cellular glass space will be held by nylon netting. The bottles will be placed by volunteers between the wall and a sheet of $30^{\prime \prime} \times 8^{\prime}$ plywood sandwiched between two sheets of agricultural film. Fill will be put between the outside ret taining.wall and the plywood slip form and as fill is added to the level of the bottles the form will be pulled up and the process repeated. The retaining wall will hold the berms edge for easier maintainance of the grounds and $t$ reduce the load of the berm on the building wall. The berm wall will be 4' from the building wall and the berm will be planted with pemanent vegitation. The retaining wall will be laid of native sandstone consistant with the older element of the campus.

The delivery system for the hot water heat is at present uninsulated 2" black pipe so that even if the radiators are shut down the circulation in the system gives off a great deal of heat. The 2" pipe will be insulated with fiberglass pipe insulation. Five hundred and thirty feet will be required. 
The potential impact on the comunity and region is manifold. Because of the nature of the institution there are many visitors from the local and regional communities. Every summer there are work camps who request project at the center. These church sponsored work camps are comprised mainly of children in middle or high school. The simplemindedness and economy of the project are visually available to those who see it. Volunteers involved in the project will be able to camcy away a hands on understanding of simple and available techniques for efficient heating and cooling. The process of the project will be documented by vide's tape through Cable $10 \mathrm{TV}$ in Frarikfort $\mathrm{Ky}$. as well as the many presentations now given regionally by the staff. A most important benefit to the conmanity and region would be in the concept that trash glass is a building block in thermal insulation. A national problem will be given the space to become a benefit and auintegral part of the food packaging industry will have an outlet into the building industry. The way I happened to come on the idea of using glass as insulation between a berm and a mass wall was a game I started playing in $1975 \mathrm{called}$ the Buffalo Robe Construction Company--our motto is "If you have enough clothes you don't need a house"! The rules of the game were to build a $1200 \mathrm{sq} \mathrm{ft}$ house in two days with 20 men with $\$ 2000$ that would be passively heated and cooled, provide part of the diet, have an expected life span of 500 years, 200 years without maintainance, use cultural scrap and on site materials-- sometinig of a cross between a tent and a culvert. In 1979 I attended a three day seminar on earth sheltered homes. I was sponsored by a man who wanted one built. I didn't build one but became acquainted with Edward Mazria's book and several in earth sheltered design. While studying the literature and visiting homes I heard of I was struck by the inconsistancy of putting up a 50 year material (extruded polystyrene) to insulate a 2000 year material (concrete). Anyway you can see the game is a mind stretcher and one night I sat up in bed and saw glass containers inverted would match the life of concrete and would provide stable cellular air space with only tangential contact between glass vessels, and inverting would provide free drainage so no water is held to increase themal conductivity--all this in a situation against a wall not to bu subjected to hydrostatic pressure. The most interesting thing for me besides being embarrassingly simple was that the materials were handled through the food chain and also that the problem of dealing wiht glass breakage would be dealt with by the appropriateness of burying it. Anyway for me BINGO trash is given mental treasure beyond the hammermill and more heat. The energy resources involved are first OIL which is expected to cost in excess of $\$ 3000$ during this present mild heating season. The purpose of the project is to shift the load from oil to solar with the Greenhouse double entry and the trombe wall and to conserve the energy needed to heat the building, and to provide cooling withe energy from the earth with the walls acting as a thermal wick. Another energy source is the thermal mass of the building itself. Another energy resource is the 20th century American distrobution system that delivers food in glass containers and building materials and also oil based insulation. Glass is the most cost effective energy use in conversion from heat to product, its drawback being its mass as compared with say aluminum. The additional mass is, in this case, a plus in that it is stmucturally ridged. Also food remains in a more stable condition in glass than any other form of packaging. Glass is the only packaging that is already oxidized. The BUCKHORN CHILDREN'S CENTER administration building was additionally apealling as the heat is hot water radiated at the base of the proposed bermed walls allowing the mass to become, in effect, additional radiation. 


\section{Benefits page 3}

The savings in the heating costs are demonstrable by the history of the building in its utility records. The importance of the savings is that monies saved will help to keep qualified staff for children and adequate maintainance of the children's home, which in fact is what the institution is, in name and spirit. The center tries to move the children to family homes within 2 years for as much of a family atmosphere exists between the children and staff it is, still an institution.

The biggest barmier to overcome is the attitude of glass trash and that efficiency in space heating is not simple and available.

The likelihood of commercialization resultirig from the project would be in container and packaging design to facilitate minimal thermal transfer through the tangentially contacted glass and the repackaging of container for placenent in the berm to minimize handling of the containers during construction. The nicest thing about this potential is that the system upon which the idea is based already exists. Additionally the demonstration of solar energy use and the effect of insulation will be shown to many in the region helping them to explore alternatives to traditional four square mentality which has left them with homes that are cold and expensive to heat.

The potential environmental impact is obvious if you drive down most any mural Kentucky road in the number of dumps of trash including glass vessels. Also the project is budgeted to pay children for the approx 15000 containers required for the project (assuming 12 vessels/sq ft)illustrating trash transformed to treasure.

Pop boitles is it on the innovative aspect of the grant and as far as $I$ know it has not been tried. I went to the University of Kentucky archetecture library and the only reference I could find to glass containers being re used was a German beer company which shipped beer to Africa in bottles shaped like bricks. The berming of the building was inspired by the Forest Service building in Berea Ky. which was built last year. I an unaware of any retrofit berming being done around here. The project will be complete within the funding period. The contracts will be let locally for the eastern Kentucky labor force whenever possible. Three bids will be taken for each phase of the project and preference will be for local firms. I believe the proposal can be easily managed because of the simplicity and size of each facet of the job. The accounting system and monies will be handled by the staff of the center. Their budget for fiscal year 80-81 is enclosed. The final architectural renderings and detailing will be done by David Banks AIA of Frankfort Ky. who participated in the developement of the proposal and cost estimates. 

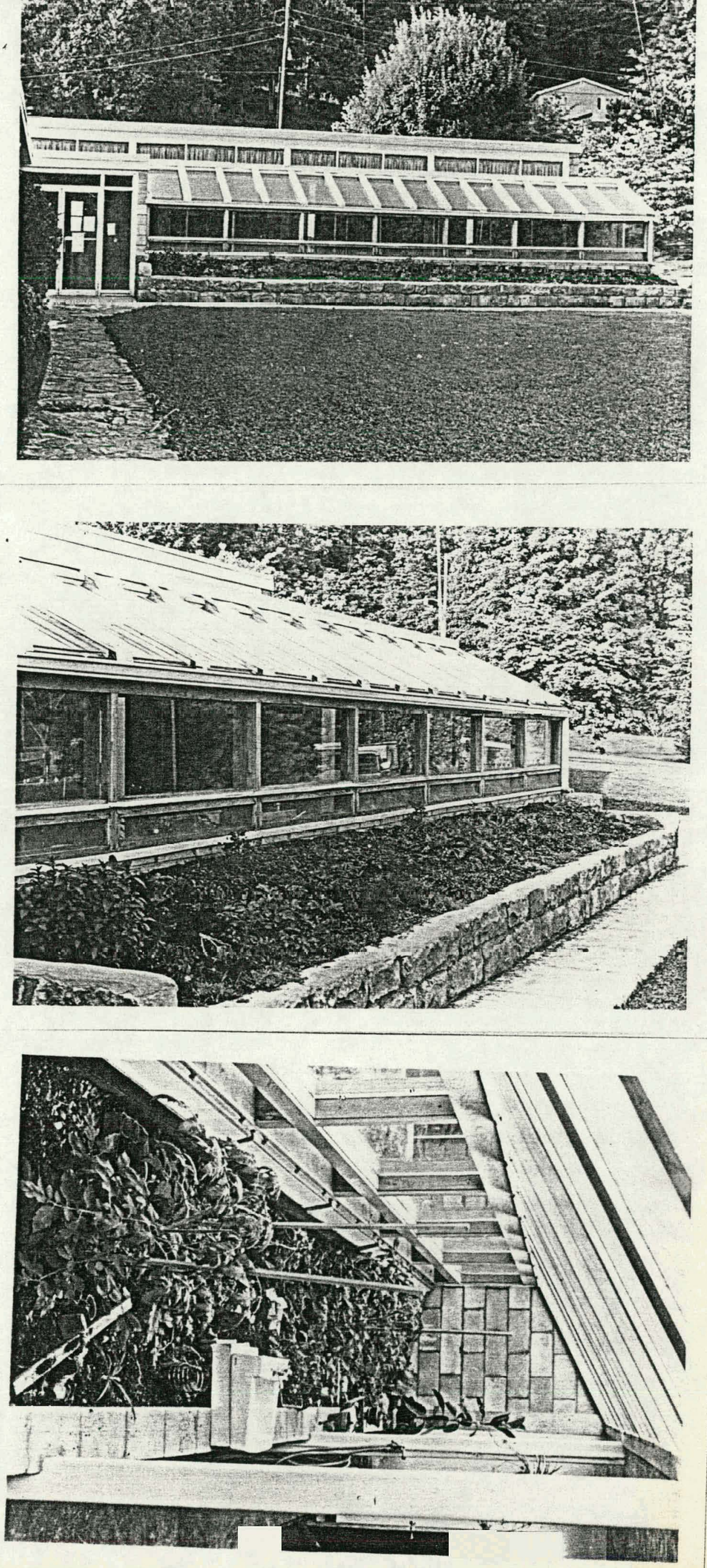

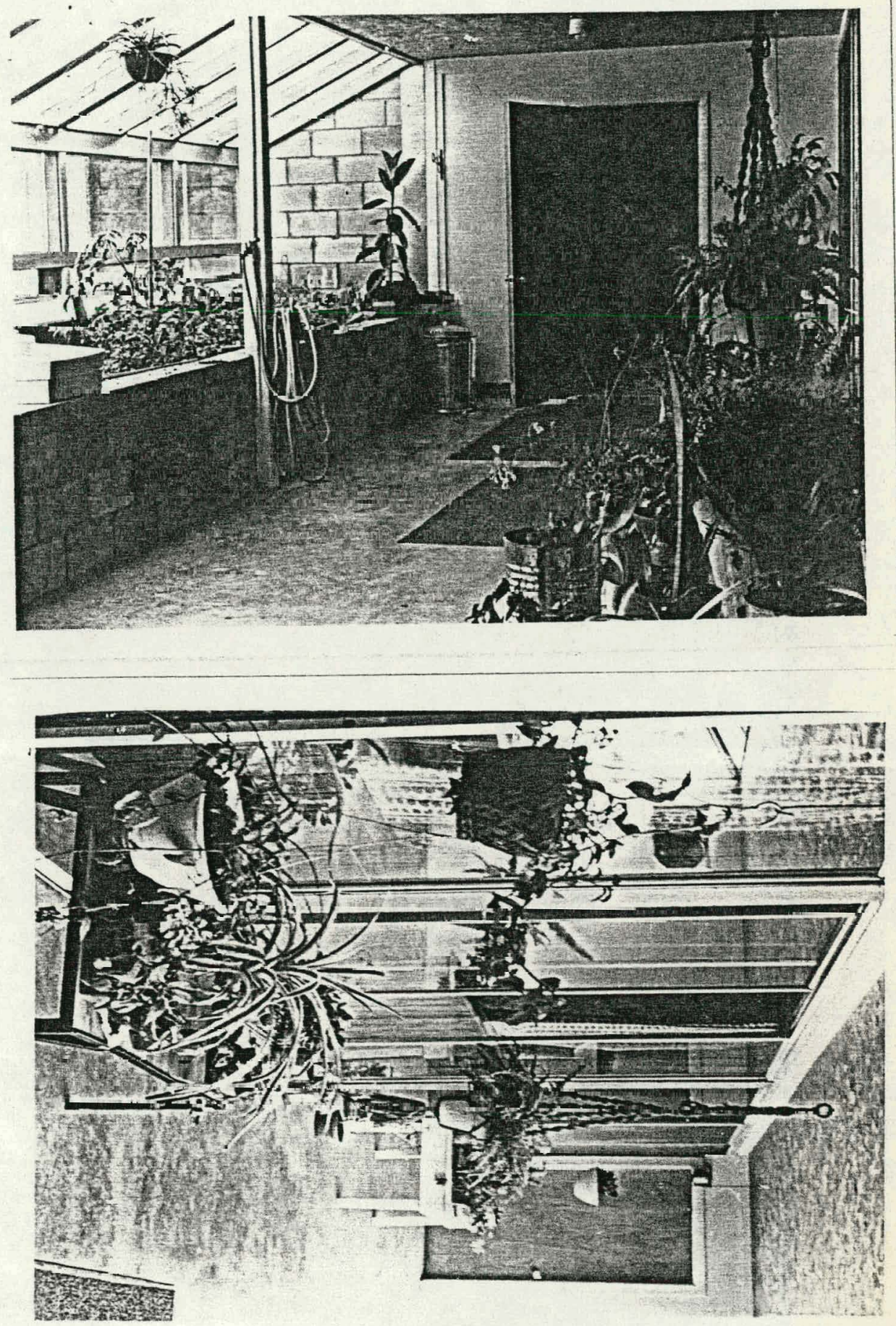